\title{
THE UNACCOMPANIED OR SEPARATED MINOR IN THE ASYLUM PROCEDURE
}

\author{
Andra Maria BREZNICEANU \\ University of Craiova, Craiova, Romania \\ andra_brezniceanu@yahoo.ro
}

\begin{abstract}
The unaccompanied or separated minor is, according to the European Union body of legislation regarding asylum and migration, one of the extremely vulnerable categories of persons, and the risk of vulnerability is amplified in the case of the unaccompanied or separated minor - asylum seeker.

Ever since the EU pre-accession period Romanian legislation reconciled, according to the European model, the requirements of the rules on migration with humanism provisions in the field of child rights. The images in the media about the migratory flows in recent years have revealed a system that requires imperatively legislative changes, adapting procedures, innovative work tools, including the case of the unaccompanied minor asylum seeker.

In this article I intend to analyze the existing legislative framework in Romania, highlighting the positive aspects of the law and those which I believe that should be reconsidered so that the interests of the minor in the asylum procedure to be properly protected.
\end{abstract}

Keywords: unaccompanied, minor, separated, asylum, migration

\section{Introduction}

The unaccompanied minor, separated from parents or from legal guardian, is one of the most vulnerable categories of asylum seekers, along with trafficked persons, people with disabilities or serious illnesses, etc.

The term minor used in Romanian legislation, both in the general [1] and the asylum-specific one [2], is similar to the usual term child used in the Convention on the Rights of the Child, according to which "child means any human being under the age of 18 , except the cases where the applicable law to the child sets the age under this limit "[3].

In order to delimit the strict framework of this article, we will refer to the definition agreed by the Romanian legislator, according to which the unaccompanied minor is a foreign child or a child without citizenship of a state who, by entering the territory of Romania, finds himself/herself in one of the following situations: a) he/she is not accompanied by parents or by an adult who is legally responsible for the minor and is not in the effective care of him/her; b) the minor who, after entering Romania, is left unaccompanied.

2. The concept of unaccompanied or separated minor in Romanian legislation From the moment of defining the category of interest - unaccompanied minors - we notice a greater strictness of the Romanian regulation vis-à-vis the international bodies regarding the asylum seekers. Thus, in UNHCR's (United Nations High 
Commissioner for Refugees) approach the unaccompanied minors are "minors who have been separated from both parents and other relatives and are not cared for by an adult who, according to law or custom, is responsible for doing so" [4], introducing into the notion of unaccompanied minors a distinct subcategory, that of minors separated by both parents or the legal guardian, but not necessarily separated from other relatives, who may actually have the role to care for the minor without having the legal attribute of his/her protection. The establishment of this subcategory was determined by the practical consideration of the fact that the unaccompanied minor is usually part of a group of asylum seekers, persons with whom it is related and in whose care it was given when leaving the country of origin without having legal documents on child protection. International institutions take into account the protection of the minor by other adult members of the extended family.

The Romanian legislator, however, inserted in the definition of the unaccompanied minor a subcategory only found in the Dublin Regulation, namely "the minor who is left unaccompanied after entering the territory of Romania"[5].The argumentation of this sub-category was determined by the sometimes justified suspicion that minors (usually persons over 14 years of age, who no longer require current care from an adult) benefit in the asylum application procedure from favorable conditions and legal guarantees of access to the territory and to the status, as a result of the unimpeded application of the principle of protecting the best interests of the child; which can justify the reason for being left apparently unaccompanied.

Another aspect that the Romanian legislator treats differently from the international institutions is that the person accompanying the juvenile must "be responsible for him/her according to the Romanian law"[6], not considering the existence of protection under the customary or legal regulations of the minor's asylum seeker's home country. A large number of these subjects (unaccompanied minors) come from countries where the custom is a recognized source of law and, at the same time, a current and prolific way of regulating legal situations.

Starting from international regulations (The UNO Convention on the Rights of the Child, art.5), from European regulations (art.5,8 from The European Convention on Human Rights, art.17 from The European Social Charter) or the casuistry of the ECHR [7], which states without exception the principle of the best interests of the child, Law no. 122/2006 also enshrines the fundamental importance of the principle, thus reconciling the protection of the child's rights with the emigration policy requirements. Article 8 of the Regulation stipulates that all decisions regarding the minor are taken with respect to its superior interest, especially when unaccompanied.

\section{The asylum procedure}

The unaccompanied minor becomes according to article 34 (1) Law no.122/ 2006 asylum seeker when manifesting the will to request the protection of the Romanian state, in oral or written form. Although the expression of will involves a personal act, most often, for the unaccompanied minor who can not express his will (young age), the request for protection is made by de facto representatives of the group he is part of. Subsequent to the oral presentation of the intention to seek asylum, the written procedure for submitting an application for asylum to the competent authorities is provided. The ambiguity of the provisions of art.34 (3), referring to art. 36 (2) of Law No. 122/2006 and Article 3 of the Dublin Regulation raise difficulties of understanding and interpreting both for the 
unaccompanied minor and for the adult asylum seeker. Thus, the Dublin Regulation provides that the Member States are responsible for examining all international protection claims made by foreigners "on the territory of any of them, including at the border or in transit zones" [8], which at least seems to contradict our legislation (there are no explanations within the methodological norms of law enforcement) that provides that the request for protection filed on the territory of the country but not directed to the authorities of the Romanian state will generate the effect of recognizing the status of asylum seeker only "at the time of the manifestation of will towards the competent Romanian authorities"[9], by this understanding the unhappy expression of the Romanian legislator that the Romanian state is responsible for examining a request for protection only if the person requests the protection of the Romanian state. At the same time, art. 36 (2) provides that "the asylum applications lodged outside the territory of Romania are not admitted"[10]. Per a contrario, the applications filed on the territory of other Member States by asylum seekers in Romania should, according to the legislator's expression, not be accepted on the grounds of being deposited outside the territory, even if Romania is designated as a responsible State according to the Regulation.

As a consequence of the expression of the will to request the protection of the romanian state, the unaccompanied minor is registered by the competent authorities as an asylum seeker, the entry into the written phase of the procedure (the filing of the asylum application) being initiated by the legal representative at the time of his appointment. Unaccompanied minors over the age of 14 may personally submit the application. The appointment of a legal representative within the Child Protection Directorate within the territorial administrative unit the competent authority is to receive the asylum application, with attributions in assisting the unaccompanied minor during the asylum procedure, according to law "instanter". It is true that European Law does not require the appointment of a legal representative for a minor even when the authorities find out about his/her existence, Article 25 of the Asylum Procedures Directive using the term "instanter" taken over by the Romanian legislator or the term "immediately" used in Art. 24 of the Asylum Conditions Directive. However, we consider that in the transposition of the directives, the national legislature is desirable to provide for a maximum term for the appointment of the representative, because the absence of a concrete term may have negative or abusive consequences on the situation of the minor, including the taking over in the accomodation institutions provided by the state. In practice, the appointment of a representative lasts between one day and seven days.

At the same time, European legislation in the field (including the Dublin Regulation, art. 25) does not require the appointment of a legal representative to assist the minor exclusively during the asylum procedure, leaving it to the States to choose for the appointment of a specialist in the asylum procedure or for a representative with wider attributions of guardian type.

From the formulation of Law no.122 / 2006, we consider that the legislator opted for the appointment of a legal representative with general competencies considering that he/she will continue to "operate for as long as the minor enjoys international protection in Romania" [11], the exercise of the rights and obligations of the asylum seeker and later of the refugees / beneficiaries of international protection being exercised with the agreement and the contest of the representative. 
We consider that the appointment of a legal representative specialized in the procedures for obtaining protection is preferable, given that he/she informs the minor about the performing of the forensic expertise for age assessment, about the personal interview and about its consequences on his situation.

The above-mentioned argument is reinforced by the legislative aspect that allows the interview to be conducted without a lawyer (art. 45 alin. 4 Law $122 / 2006$ ), the minor being throughout the personal interview assisted only by the legal representative, which is why we consider that the appointment, in the presented conditions, of a representative specialized in the legislation and casuistry of the asylum is preferable to a representative with general protection valences of the minor.

Targetting the child's best interests - family reunification or avoidance of separation in the situation in which members of the same family make asylum applications on the territory of different states - Dublin Regulation introduces the obligation in the case of unaccompanied minors for the states to identify the Member State responsible for the applicant of asylum, according to a scale of the minor belonging to the family or to a group.

In this respect, the application submitted by the minor is to be examined by the state on whose territory the family members are legally included, including brother, sister or a relative who, after an individual examination carried out by the state on whose territory he or she is, justifies the possibility to take care of the minor. The existence of family members of the minor on the territories of several Member States determines the European legislator to assess the interest of the child in identifying the responsible state and not just granting the responsibility of any state where a member of the family has been identified. The nonidentification of the family members of a family member, including the extended family, is the state in which the minor submitted the asylum application, "provided that this is in the best interests of the minor" [12].

However, the regulation does not clarify how the application is solved and by which state if the maintenance of the minor in the state where the application was filed is not in his/her interest.

The case of the unaccompanied minor is offered, according to the European and national legislation, a series of other technical guarantees to defend his or her best interests:

- the refusal of forensic expertise to determine the age in cases where there are serious doubts (determined by general statements or by analysis of some conclusive evidence of the case) regarding the minority does not necessarily lead to the person being considered as adult, if grounds for refusal are invoked or if conclusive evidence of age, including the last medical examination in the country of origin are provided. European regulations allow states to use certain techniques or medical analyzes in the process of determining the actual age of the person. The refusal by the state authorities of the request for protection cannot be based solely on the refusal of the minor to undergo a medical examination of the age;

- the interpretation of the result of the expertise is done in accordance to the principle of the child's interest;

- digital photography and fingerprinting of the minors under 14 are not carried out;

- the minor's personal interview is adapted to the age and degree of intellectual maturity, not being realized if the minor is too small to participate to such a procedure; - the request for protection of the unaccompanied minor is analyzed as a matter of priority.

The permissiveness of the law in granting the possibility for the juvenile over 14 to 
submit a request for protection in its own name as well as of the juvenile over 16 to submit in its own name a complaint against the decision of resolution of the asylum seeker request, is part of the extended collateral body offered by EU Member States to the unaccompanied minor.

The examination of minors' requests through the accelerated procedure, in transit zones or state borders are considered exceptions, being processed only under the terms of Directive no.2013/32/EU (art. 25).

- the minor's accommodation "is carried out in a residential service belonging to the general directorate for social assistance and child protection or an authorized private body" [13] or in the reception centers if the minors are over 16 years old.

Within the framework of the Directive no. 2011/95 / EU priority is given to the placement of the minor to relatives or to other (substitutive) host families at the expense of the institutionalized type (to which the Romanian legislator stops) in order to attenuate the exposure of the juvenile to cultural shock as far as possible (not knowing the language, habits, entourage people).

The detention of unaccompanied minors is forbidden in principle, the cases in which it is permitted exclude compulsory detention in prisons;

- starting with urgency the steps to identify family members both in safe states and in home countries. In order to protect the minor and the family members remaining in the country of origin, the collection of information is done with strict respect of the confidentiality of the data.

Enhanced guarantees granted by EU countries or by Romania to unaccompanied minors do not exclude the possibility of a negative solution of their asylum requests, as well as the refusal of a right to stay in the territory during the review of the protection request, provided the protection of the minor's best interest.

\section{Conclusions}

The adoption by the EU (and the transposition into national legislation) of some novator and visionary legislative regulations starting with 2011 and the existence of common procedures of the Member States in the field of asylum (including the asylum of the unaccompanied / separated minor seeker) had the merit to prevent many of the day-today difficulties of protection seekers and to provide responsible and functional support in the context of the 2015-2017 migration exodus.

The joint legislative approach of states has facilitated the access of unaccompanied minors to extended safeguards in the asylum procedures, for the most part of the EU member states, including Romania (the clarification of some useful notions in the Romanian legislation - respectively the term "instanter" from article 16 Law $122 / 2006$; the statute of the juvenile's legal representative - being expected).

\section{References}

[1] Romanian Civil Code-Law no.287/2009, Monitorul Oficial no.505/15.07.2011, art.38 (2);

[2] Law no. 122/2006, Monitorul Oficial no.428/18.05.2006, art.1;

[3] The Convention on the Rights of the Child ratified by Law no. 18/1990, published in the Monitorul Oficial no. 109 /28.09.1990 and republished in Monitorul Oficial, no. 314/ 13.06.2001, art.1

[4] UNHCR Guidelines on Determining the Best Interests of the Child, p.7; retrivied from http://www.unhcr.org/ro/wpcontent/uploads/sites/23/2016/12/Guidelines_Best_interest_of_the_Child.pdf 
[5] (EU) Regulation no. 604/2013,art.2, retrivied from http://eur-lex.europa.eu/legalcontent/RO/TXT/?uri=CELEX:32013R0604

[6] Law no. 122/2006, Monitorul Oficial no.428/18.05.2006, art.2 (1);

[7] http://hudoc.echr.coe.int/eng\#\{"itemid":["001-104366"]\}

[8] (EU) Regulation no. 604/2013,art.3(1) retrivied from http://eur-lex.europa.eu/legalcontent/RO/TXT/?uri=CELEX:32013R0604

[9] Law no. 122/2006, Monitorul Oficial no.428/18.05.2006, art.34(3);

[10] Law no. 122/2006, Monitorul Oficial no.428/18.05.2006, art.36(2);

[11] Law no. 122/2006, Monitorul Oficial no.428/18.05.2006, art.40(1);

[12] (EU) Regulation no. 604/2013,art.8(4), retrivied from http://eur-lex.europa.eu/legalcontent/RO/TXT/?uri=CELEX:32013R0604

[13] Law no.272/ 2004, Monitorul Oficial no.159/05.03.2014, art.8 (1,2) 